\title{
SPECIES COMPOSITION OF LEAF FOOTED BUGS (COREIDAE: HEMIPTERA) IN HILLY REGIONS OF NEPAL
}

\author{
S. KC*, K. Kafle and A. Khadka \\ Lamjung Campus, Institute of Agriculture and Animal Science \\ *sajankc143@gmail.com
}

\begin{abstract}
A survey of leaf footed bugs (Hemiptera: Coreidae) was conducted in two hilly districts of Nepal viz. Lamjung and Kaski, over a period of 13 months (April 2017-May 2018). The prime purpose of the research was to find out the Coreidae diversity in these regions which hasn't been done before. Sundarbazar, Kunchha and Dura Daanda areas from Lamjung and Hemja and Sarangkot from Kaski were explored. A total of 111 specimens of Coreidae were collected from altitude varying from 700-1600 masl. Eleven different species of these bugs from 1 subfamily, 7 tribes and 7 genera were recorded. All the species fell under single subfamily Coreinae Leach, 1815. One species, Acanthocoris scabrator (Fabricius, 1803) fell under the tribe Acanthocorini Bergroth, one species, Leptoglossus gonagra (Fabricius, 1775) fell under tribe Anisoscelini Laporte, one, Cloresmus khasianus (Distant, 1901) under Cloresmini (Stal) and one, Dalader acuticosta (Amyot \& Serville, 1843) under Daladerini Stal. Similarly, 3 species viz. Cletus bipunctatus (Herrich-Schäffer, 1840), Cletus pygophorus (Gupta \& Singh, 2013) and Cletus trigonus (Thunberg, 1783) fell under the tribe Gonocerini Mulsant and Rey. Likewise, 3 species were found under the tribe Homoeocerini Amyot and Serville viz. Homoeocerus (Anacanthocoris) striicornis (Scott, 1874), Homoeocerus (Anacanthocoris) sp. and Homoeocerus (Tliponius) unipunctatus (Thunberg, 1783) and 1 species, Anoplocnemis phasianus (Fabricius, 1781) was found under Mictini Amyot and Serville.
\end{abstract}

Key Words: Coreidae, Kaski, Lamjung, Leaf Footed Bugs, Diversity

\section{INTRODUCTION}

Coreidae is a large family of the suborder Heteroptera within the infraorder Pentatomorpha. It was established by Leach in 1815. It lies within the superfamily Coroidea (Leatherbugs) along with prominent families like Alydidae, Rhopalidae and two other small old world families. It contains close to 1900 spp. in about 270 genera (Henry, 2009). They have a wide distribution with most diversification in the South and Southwest regions.

They have a four segmented antennae and 4 segmented beak. 2 ocelli are present and tarsi is 3 segmented. Antennae insertion is at the upper parts of head sides. Head is narrower and often shorter than the pronotum. Juga don't enclose the tylus anteriorly. They are called leaf footed bugs as some species have leaf like expansion in their hind tibiae. Abdominal margin in many species is raised with the folded wings lying in the depression caused by the raised margins (Arnett, 2000). They often produce an unpleasant odor as a defensive secretion from the thoracic glands when disturbed (Eisner, 2003). All the species are exclusively plant feeders (Arnett, 2000). They are phytophagous and majority of them live on plants above the ground feeding on plant vascular system (Kumar, 1966). However, occasion coprophagy is also known (Steinbauer 1996). Many of them are pests of various crops that can sometimes cause serious damage to total loss (Henry, 2009). Their feeding habits can cause serious problems like malformations, rotting, discoloration, fruit abortion and poor seed formation (Mitchell 2000). Eggs are brown, oval and typically cemented beneath foliage of host. Adults sometimes overwinter. 
Review of the available literature revealed only a few studies on the species composition of Coreidae in Nepal with no specific mention about the previous records from the study areas. Those researches too were done in the distant past from now. Joshi and Manandhar (2001) described 10 species from Nepal under 6 genera studying the species most of which were collected during 1962-1986. Four of those species belonged to Leptocorisa genus which was mistakenly included under Coreidae. Similarly, Thapa (2000) listed 9 species from Nepal under 7 genera out of which Leptocorisa acuta was again included under Coreidae. According to the fauna of British India (Distant, 1902, 1908, 1910), under Coreidae there are 143 species under 45 genera available in India, of which many could be found in Nepal.

The Coreidae fauna of the Nepal is rich and diverse, but remains very poorly studied as compared to those from other zoogeographical domains of the world. The present study was undertaken to investigate the species composition of Coreidae within the hilly domains of the Nepal. The study would further encourage the researchers to undertake and explore the leaf footed bugs from various parts of these regions.

\section{MATERIALS AND METHODS}

The study was carried out during April 2017-May 2018. Collection trips to the nearby forest areas, rice and other crop fields was made in several locations of Lamjung and Kaski district; Sundarbazar, Kunchha and Dura Daanda in Lamjung and Hemja and Sarangkot in Kaski. The sightings were recorded capturing photos in Gionee P5W smartphone with a 5 MP camera. The date of sightings (precise with time of sighting) and the location with latitude, longitude could be extracted from the photo details. The bugs were collected using sweep nets, however careful hand collection was also effective to great extent. Collected specimens were killed in killing jar containing a cotton plug soaked with ethyl acetate. The captured specimens were taken to the Entomology Laboratory of Lamjung Campus, IAAS, TU (Sundarbazar-7, Lamjung). Nymphs were taken and reared till adults emerged which were then identified and carded using standard procedure.

Identification was done referring to the available databases, dichotomous keys, various published literatures, comparison with authentic images and illustrations and senior scientists' help.

Table 1: Location and altitude of collection sites

\begin{tabular}{llll}
\hline S.N. & District & Location & Altitude (masl) \\
\hline & & Sarangkot & \\
& & $28^{\circ} 14^{\prime} \mathrm{N}$ & $1,100-1,600$ \\
& & $83^{\circ} 57^{\prime} \mathrm{E}$ & \\
& Hemja & $1,000-1,120$ \\
& $28^{\circ} 16^{\prime} \mathrm{N}$ & \\
& $83^{\circ} 56^{\prime} \mathrm{E}$ & $625-700$ \\
& Kaski & Sundarbazar & \\
& & $28^{\circ} 7^{\prime} \mathrm{N}, 83^{\circ} 24^{\prime} \mathrm{E}$ & \\
& & Kunchha & \\
& & $28^{\circ} 8^{\prime} \mathrm{N}$ & \\
& $84^{\circ} 20^{\prime} \mathrm{E}$ & \\
& & Dura Danda & $1,000-1,100$ \\
& & $28^{\circ} 9^{\prime} \mathrm{N}$ & \\
& & $84^{\circ} 21^{\prime} \mathrm{E}$ & \\
& &
\end{tabular}




\section{RESULT AND DISCUSSION}

This list reports 11 species of Coreidae under 7 genera, 1 subfamily and 7 tribes from hilly regions of Nepal.

Oder: Hemiptera

Suborder: Heteroptera

Family: Coreidae

V.K. Thapa (2000) hinted the rarity of the identified species on the basis of the number of specimens collected or that available for study.

- Rare: Only 1 specimen collected

- Uncommon: Only 2 specimens collected

- Less common: 3-5 specimens collected

- Rather common: 6-10 specimens collected

- Common: 10-50 specimens collected

- Quite common: More than 50 specimens collected

\section{Coreids collected:}

Subfamily: Coreinae Leach, 1815

Tribe: Acanthocorini Bergroth

i. Acanthocoris scabrator (Fabricius, 1803)

- Material Examined: Sundarbazar, Lamjung, Nepal, 2017.vii.17, Coll. Anjali Khadka

- Habitat: Forest

- Rather Common

Description: Body $13 \mathrm{~mm}$ long and $5.1 \mathrm{~mm}$ wide. Body is brownish color. Body, including the antennae, is extremely hairy. Pronotum margins sinuate, humeral angles slightly produced forming short spines. Connexivum brown with orange suffusion across articulation of segments. Membrane is chocolaty brown. Ventral side is light brown with black spots scattered. Rostrum just touching the mid coxae. Legs covered with long setae. Hind femur much swollen.

Remarks: Specimens with body color black were found as well.

Distribution: India: Sikkim, Meghalaya, Himachal Pradesh and Uttarakhand (Gupta, 2013); Assam, Sikkim, West Bengal (Prabakar, 2015), Nepal (Joshi, 2001).

\section{Tribe: Anisoscelini Laporte}

\section{ii. Leptoglossus gonagra (Fabricius, 1775)}

- Material Examined: (1) Sundarbazar, Lamjung, Nepal, 2017.vii.30, Coll. Sajan K.C. (2) Kunchha, Lamjung, Nepal, 2018.i.09, Coll. Anjali Khadka

- Habitat: Bitter Gourd (2) Zucchini

- Less Common

Description: Adult has body $20.8 \mathrm{~mm}$ long and $6 \mathrm{~mm}$ wide. Body is black. 2 orange longitudinal lines are present on head joining ocelli to the base. An orange transverse fascia on anterior pronotum curved to reach the base of humerus. Spiny humerus. 3 tiny orange spots on each corner of the scutellum. 2 small orange spots in the center of corium. I, II and III segments of antenna black. Last segment luteous with fuscous base. Ventrum black with several orange patches. 2 orange longitudinal lines drawn across the lateral sides of head. Femurs have rows of spines reaching halfway from distal part. Hind tibia dilated, leaf like, with inner part less than 50\% dilated of whole tibiae and outer part more than $50 \%$ dilated. An orange streak in the center of inner dilation of hind tibia. 4 segmented 
rostrum reaching third abdominal segment. Connexivum with orange suffusion across articulation of segments.

Body is $20 \mathrm{~mm}$ long and $6 \mathrm{~mm}$ wide. Body is of brown color. Head has 3 longitudinal lines instead of 2; 1 running from tylus to little beyond ocelli and 2 running from juga to base of head. Antennae I segment black, II black with center portion orange, III with base black and equal orange and black portion above it, IV with apex orange and base fuscous. Pronotum has orange line across margins. Transverse orange fascia same as in previous form. Scutellum and corium spots same. Ventrum brown with orange spots much bolder and denser than previous form. Legs brown. Femurs spinous in similar fashion as previous form. Inner dilation of hind tibia has an orange streak in center that extends slightly to the outer dilation.

Distribution: United States of America, Puerto Rico, Cuba, Mexico, Belize, Guatemala, El Salvador, Nicaragua, Venezuela, Ecuador, Brazil, Bolivia, Paraguay and Argentina to Africa, Asia, Australia and the Pacific Islands (Maes \& Goellner-Scheiding, 1993; Packauskas, 2010; Fent \& Kment, 2011; Brailovsky, 2014).

\section{Tribe: Cloresmini Stal}

\section{iii. Cloresmus khasianus (Distant, 1901)}

- Material Examined: Sundarbazar, Lamjung, Nepal, 2017.viii.05, Coll. Sajan K.C.

- Habitat: Bamboo

- Rare

Description: Adult has body $16 \mathrm{~mm}$ long and $4 \mathrm{~mm}$ wide. Dorsum has a metallic green shine with brown membrane. Reddish brown eyes. Last segments of antennae ochraceous. Black suffusion on articulation of pale brown connexivum. Pleurites and prosternum metallic green, meso and metasternum fuscous with center portion brownish. Sternites are reddish brown. Legs are brown. Enlarged hind femurs with a spine in the central inner margin. Inner distal margin of femurs with few small spines. Inner margin of hind tibiae with crenulation. Rostrum pale brown and very short just exceeding procoxae.

Distribution: Assam, Meghalaya, Sikkim and West Bengal (Prabakar, 2015).

\section{Tribe: Daladerini Stal}

\section{iv. Dalader acuticosta (Amyot \& Serville, 1843)}

- Material Examined: Sarangkot, Kaski, Nepal, 2017.v.23, Coll. Anjali Khadka

- Habitat: Forest

- Common

Description: Adult has flat body $30 \mathrm{~mm}$ long and $16 \mathrm{~mm}$ width at widest part. Highly widened connexivum about $3.5 \mathrm{~mm}$ long. Body color reddish brown. A thin light brown commissural line joining proximal to distal pronotum. Humerus extended into thick curved spines. Membrane is light brown. III segment of antennae foliaceously dilated on each side and IV segment is ochraceous. Other segments are fuscous. Connexivum reddish brown with light patches in between. Ventral side reddish brown. Legs are reddish brown with ochraceous setae which are denser on tarsi.

Distribution: Myanmar; India: West Bengal, Sikkim, Assam, Meghalaya and Himachal Pradesh (Gupta, 2013); Borneo (Prabakar, 2015), Nepal (Thapa, 2000). 


\section{Tribe: Gonocerini Mulsant and Rey}

v. Cletus bipunctatus (Herrich-Schäffer, 1840)

- Material Examined: Sundarbazar, Lamjung, Nepal, 2018.iv.23, Coll. Sajan K.C.

- Habitat: Amaranthus spinosus

- Common

Description: Adult has elongated subcompressed body with length $9.5 \mathrm{~mm}$ and breadth $3.2 \mathrm{~mm}$. Distance between two angles of humeri is $4 \mathrm{~mm}$. I and III antennal segment reddish brown, II dark brown and IV segment clubbed, pubescent with apex light brown and small part of base dark brown. Anterior pronotum yellowish brown and posterior part is dark brown. The black punctures in pronotum are denser toward posterior side. Angle of humerus acute and dark brown. Scutellum is the color of anterior pronotum. Body dark brown and membrane brassy. Body densely punctate. Connexivum pale yellow and ventral side creamish with several prominent black dots. Legs light brown with prominent black spots on femur. Rostrum with III, IV and IV segment more brownish, IV segmented with last segment darker touching hind-coxae. A whitish spot on caudal apex of scutellum, 2 whitish spots on apical edge of corium near the membrane.

Distribution: India: Assam, Karnataka, Manipur, Meghalaya, Sikkim, Tamil Nadu and West Bengal; Indonesia and Java (Prabakar, 2015); Sri Lanka, Myanmar (Gupta, 2013).

vi. Cletus pygophorus (Gupta \& Singh, 2013)

- Material Examined: Sundarbazar, Lamjung, Nepal, 2018.iv.23, Coll. Sajan K.C.

- Habitat: Amaranthus spinosus

- Common

Description: Adult has elongated subcompressed body with length $8.1 \mathrm{~mm}$ and breadth $3 \mathrm{~mm}$ in the center. I, II and III antennal segment reddish brown, IV segment clubbed, pubescent and dark brown with apex light brown. Anterior pronotum yellowish and posterior part is reddish brown. The black punctures in pronotum are denser toward posterior side. Spine of humerus small subacute and brown. Scutellum is the color of anterior pronotum. Body reddish brown and membrane light brown. Body densely punctate. Connexivum and ventral side pale greenish. Pale green coxae and pale brown legs. Small black spots on ventral side and legs. Rostrum pale brownish, IV segmented with last segment darker crossing mid-coxae but not touching hind-coxae. A whitish spot on caudal apex of scutellum, 2 whitish spots on apical edge of corium near the membrane. Membrane is brownish hyaline.

Remarks: Not all individuals have 2 whitish spots on edge of corium near membrane. Found along with $C$. bipunctatus in Amaranthus spinosus but can be differentiated from above points. Especially from the large spines of $C$. bipunctatus.

Distribution: India: Himachal Pradesh and Uttarakhand (Gupta, 2013)

\section{vii. Cletus trigonus (Thunberg, 1783)}

- Material Examined: Sundarbazar, Lamjung, Nepal, 2017.vii.30, Coll. Sajan K.C.

- Habitat: Forest

- Rather Common

Description: Adult has elongated and subcompressed body $8.3 \mathrm{~mm}$ in length and $2.8 \mathrm{~mm}$ in width. Posterior pronotum, scutellum, clavius and corium are brown. Anterior pronotum and head brownish yellow. Anterior pronotum has two blackish spots. Spine of humerus prominent with apex black and posterior margin crenulate. A tiny whitish dot on caudal apex of scutellum. 2 whitish spots on apical edge of corium near the membrane. Antennae with base reddish, II and III segments 
ochraceous, last segment clubbed, brown with light brown apex. Ventrum and legs pale yellowish brown. Ventrum has several scattered black spots. 2013)

Distribution: Sri Lanka; Borneo; Philippines; India: West Bengal and Uttarakhand (Gupta,

\section{Tribe: Homoeocerini Amyot and Serville}

viii. Homoeocerus (Anacanthocoris) striicornis (Scott, 1874)

- Material Examined: Sundarbazar, Lamjung, Nepal, 2017.vi.11, Coll. Sajan K.C.

- Habitat: Meliaceae

- Common

Description: Adult has body with length $20 \mathrm{~mm}$ and breadth $5 \mathrm{~mm}$. Brown eyes. Antennae 4 segmented chestnut brown with base and apex of IV segment whitish. Corium and clavius brownish. Edge of corium with a distinct black line. Pale greenish femurs with reddish brown tibiae. Scutellum pale greenish just like femurs. Pronotum greenish with a projection on each humerus. Margins of pronotum and humerus brownish. A fine black line passing through lateral edges of pronotum. Connexivum greenish with pubescence and ventral side pale greenish. Rostrum pale, just reaching the mid-coxae.

Distribution: India: Assam, Maharashtra, Sikkim, Uttarakhand and West Bengal (Prabakar, 2015); Sri Lanka (Gupta, 2013).

\section{ix. Homoeocerus (Anacanthocoris) sp. javanicus?}

- Material Examined: Dura Daanda, Lamjung, Nepal, 2017.vi.07, Coll. Sajan K.C.

- Habitat: Meliaceae

- Common

Description: Adult is $16.5 \mathrm{~mm}$ long and $5.2 \mathrm{~mm}$ wide. Clavius and corium are variegated brown. Membrane is uniform brown. Scutellum green. Pronotum is pale green with margins and distal part brown. The brown line on margins of pronotum extend up to the tip of head. Antennae with luteous bases and fuscous apices except for last segment in which base and apex are ochraceous and central portion is fuscous. Connexivum green. Ventrum and legs greenish. Rostrum just reaching the mid-coxae. Tibiae are brownish green with brownish tarsi and claws. Two white spots on each corium, the inner spot seems like the fusion of two spots, so sometimes 5 or 6 spots might appear.

Remarks: Couldn't be identified to species level due to lack of enough data. Javanicus is only the suspected species.

Distribution: Assam (Prabakar, 2015).

\section{x. Homoeocerus (Tliponius) unipunctatus (Thunberg, 1783)}

- Material Examined: Kunchha, Lamjung, Nepal, 2017.vi.11, Coll. Sajan K.C.

- Habitat: Forest

- Rather Common

Description: Adult has $12.8 \mathrm{~mm}$ long and $4.5 \mathrm{~mm}$ wide body. Entire body is light brown. Ventrum and pronotum margins ochraceous. Legs brown. Eyes ochraceous. A black spot on center of each corium. Antennae dark brown with last segment pubescent and lighter shade. Rostrum just reaching mid-coxae.

Distribution: Myanmar; Sri Lanka; Pakistan; India: Meghalaya, Himachal Pradesh and Uttarakhand (Gupta, 2013). 
Tribe: Mictini Amyot and Serville

xi. Anoplocnemis phasianus (Fabricius, 1781)

- Material Examined: Sundarbazar, Lamjung, Nepal, 2017.vi.17, Coll. Anjali Khadka

- Habitat: Faba Bean

- Common

Description: Adult has long elongated body 30mm long and 9mm wide. Clavius and corium reddish brown. Membrane shiny light brown. Scutellum, pronotum and head fuscous. Last segment of antennae brownish, matching the color of membrane. A thin light brown commissural line joining proximal to distal pronotum. Connexivum, legs and ventrum fuscous. Hind femur heavily enlarged with 3 spines. One on upper margin of proximal part, one little below the middle part and one in the lower inward margin on distal part. Eyes brown. Ventrum and legs densely setaceous.

Remarks: Female specimens don't have enlarged hind-femur.

Distribution: Sri Lanka; Myanmar; India: Sikkim, Meghalaya, Nagaland, Maharashtra, Karnataka and Kerala (Gupta, 2013).

Table 1: Description of species recorded at the study site

\begin{tabular}{|c|c|c|c|c|}
\hline S.N. & Species & Author & $\begin{array}{l}\text { Number of } \\
\text { specimens } \\
\text { Recorded }\end{array}$ & Area \\
\hline \multicolumn{5}{|c|}{$\begin{array}{l}\text { Subfamily: Coreinae Leach, } 1815 \\
\text { Tribe: Acanthocorini Bergroth }\end{array}$} \\
\hline i. & $\begin{array}{l}\text { Acanthocoris } \\
\text { scabrator }\end{array}$ & Fabricius, 1803 & 8 & $\begin{array}{l}\text { Sundarbazar, } \\
\text { Sarangkot }\end{array}$ \\
\hline \multicolumn{5}{|c|}{ Tribe: Anisoscelini Laporte } \\
\hline ii. & $\begin{array}{l}\text { Leptoglossus } \\
\text { gonagra }\end{array}$ & Fabricius, 1775 & 3 & Sundarbazar, Kunchha \\
\hline \multicolumn{5}{|c|}{ Tribe: Cloresmini Stal } \\
\hline iii. & Cloresmus khasianus & Distant, 1901 & 1 & Sundarbazar \\
\hline \multicolumn{5}{|c|}{ Tribe: Daladerini Stal } \\
\hline iv. & Dalader acuticosta & $\begin{array}{c}\text { Amyot \& } \\
\text { Serville, } 1843\end{array}$ & 12 & All Locations \\
\hline \multicolumn{5}{|c|}{ Tribe: Gonocerini Mulsant and Rey } \\
\hline v. & Cletus bipunctatus & $\begin{array}{c}\text { Herrich-Schäffer, } \\
1840 \\
\end{array}$ & 14 & $\begin{array}{c}\text { Sundarbazar, Kunchha, Dura } \\
\text { Daanda, Hemja }\end{array}$ \\
\hline vi. & Cletus pygophorus & $\begin{array}{c}\text { Gupta \& Singh, } \\
2013\end{array}$ & 16 & Sundarbazar, Kunchha, Sarangkot \\
\hline vii. & Cletus trigonus & Thunberg, 1783 & 8 & Sundarbaazr, Kunchha \\
\hline \multicolumn{5}{|c|}{ Tribe: Homoeocerini Amyot and Serville } \\
\hline viii. & $\begin{array}{c}\text { Homoeocerus } \\
\text { (Anacanthocoris) } \\
\text { striicornis }\end{array}$ & Scott, 1874 & 16 & $\begin{array}{l}\text { Sundarbazar, Sarangkot, } \\
\text { Kunchha, Dura Daanda }\end{array}$ \\
\hline ix. & $\begin{array}{c}\text { Homoeocerus } \\
\text { (Anacanthocoris) sp. } \\
\text { javanicus? }\end{array}$ & -- & 11 & $\begin{array}{l}\text { Dura Daanda, } \\
\text { Sundarbazar, Kunchha }\end{array}$ \\
\hline $\mathrm{x}$. & $\begin{array}{l}\text { Homoeocerus } \\
\text { (Tliponius) } \\
\text { unipunctatus }\end{array}$ & Thunberg, 1783 & 8 & Kunchha, Sundarbazar \\
\hline \multicolumn{5}{|c|}{ Tribe: Mictini Amyot and Serville } \\
\hline xii. & $\begin{array}{l}\text { Anoplocnemis } \\
\text { phasianus }\end{array}$ & Fabricius, 1781 & 14 & $\begin{array}{l}\text { Sundarbazar, Kunchha, Dura } \\
\text { Daanda }\end{array}$ \\
\hline & Total Specimens & & 111 & \\
\hline
\end{tabular}



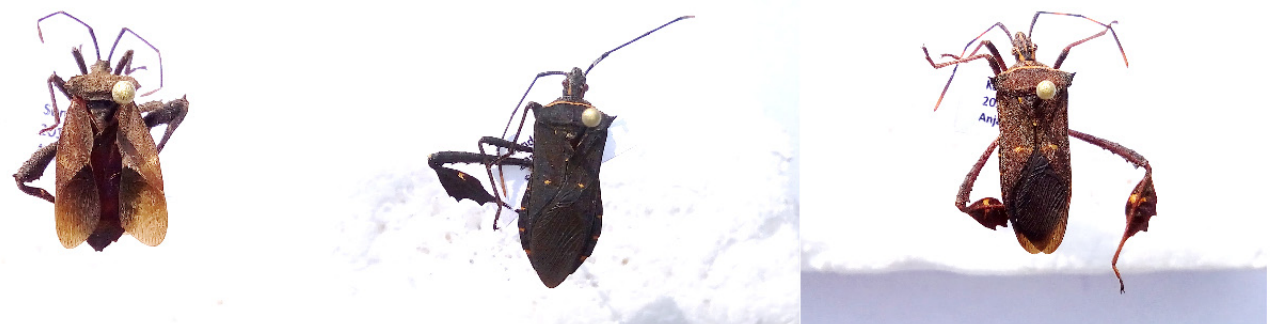

1

2

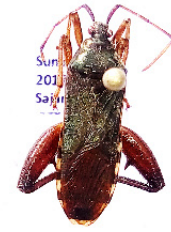

4
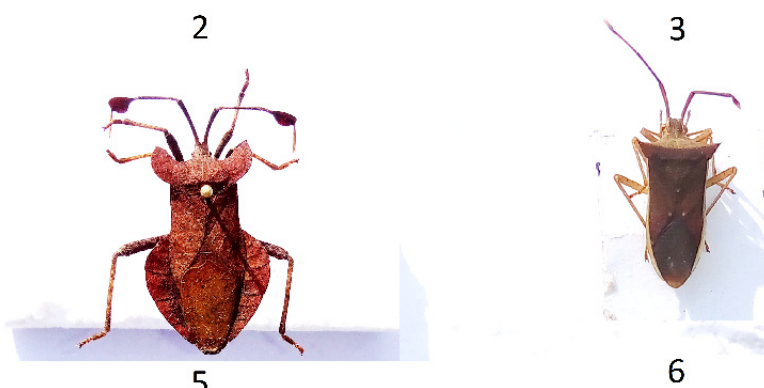

Fig: 1. Acanthocoris scabrator 2. Leptoglossus gonagra 3. Leptoglossus gonagra 4. Cloresmus khasianus 5. Dalader acuticosta 6. Cletus bipunctatus

Plate 2:

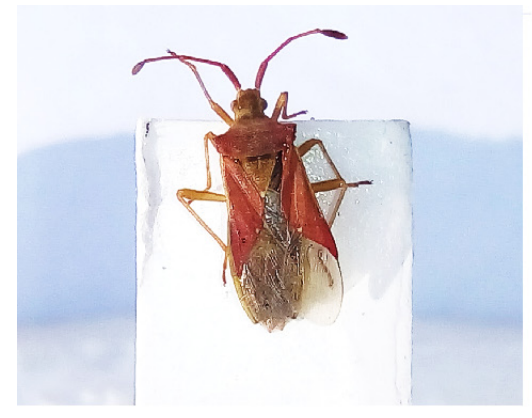

7

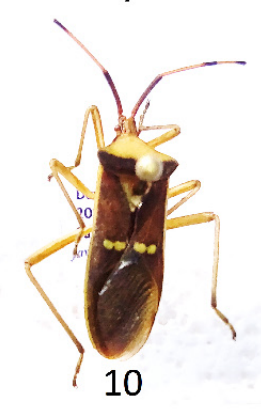

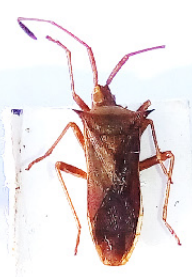

8

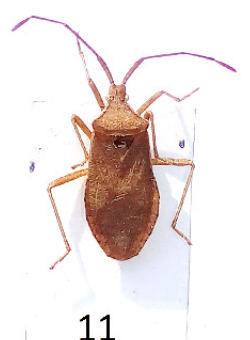

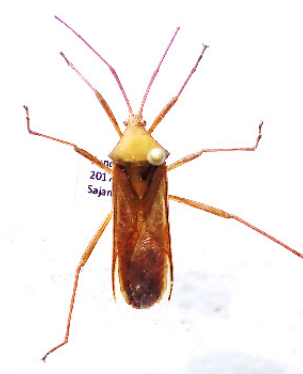

9

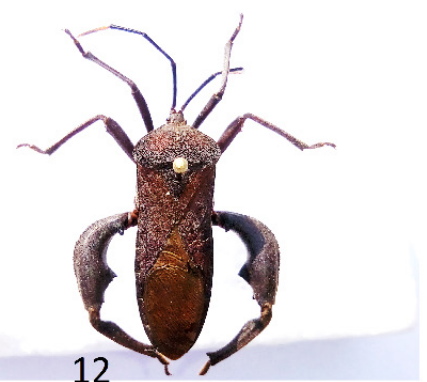

Fig: 7. Cletus pygophorus 8. Cletus trigonus 9. Homoeocerus (Anacanthocoris) striicornis 10. Homoeocerus (Anacanthocoris) sp. javanicus? 11. Homoeocerus (Tliponius) unipunctatus 12. Anoplocnemis phasianus 


\section{CONCLUSION}

This paper deals with eleven different species of Coreidae recorded from Lamjung and Kaski districts of Nepal. They belong to 1 subfamily, 7 different tribes and 7 different genera. The species were Acanthocoris scabrator (Fabricius, 1803), Leptoglossus gonagra (Fabricius, 1775), Cloresmus khasianus (Distant, 1901), Dalader acuticosta (Amyot \& Serville, 1843), Cletus bipunctatus (Herrich-Schäffer, 1840), Cletus trigonus (Thunberg, 1783), Cletus pygophorus (Gupta \& Singh, 2013), Homoeocerus (Anacanthocoris) striicornis (Scott, 1874), Homoeocerus (Anacanthocoris) sp. javanicus?, Homoeocerus (Tliponius) unipunctatus (Thunberg, 1783) and Anoplocnemis phasianus (Fabricius, 1781). Among these species, Acanthocoris scabrator was mentioned by Joshi, 2001 and Dalader acuticosta was mentioned by Thapa 2000, while the genera Cletus and Cloresmus have been recorded by both Joshi 2001 and Thapa 2000, and Homoeocerus has been recorded by Joshi 2001.

Similarly, on the basis of rarity, among these species, Cletus pygophorus and Homoeocerus (Anacanthocoris) striicornis were found to be the most common ones followed by Cletus bipunctatus and Anoplocnemis phasianus. Likewise, only 1 specimen Cloresmus khasianus was found making it substantially rare.

While the record presents a list of Coreids found in these areas, the number of species that could be found is not confined to it. Further researches are required regarding the areas that were not covered in this study to fully explore the Coreidae fauna of Lamjung and Kaski. The total area Lamjung District is about 1,692 square kilometers while that of Kaski District is about 2,017 square $\mathrm{km}$.

This research only covers a part of these districts due to the limitations in time and funding. Needless to say, there is a huge potentiality of further and newer species of Coreidae being discovered from these areas, if fully and properly explored.

\section{ACKNOWLEDGEMENT}

First and foremost the authors would like to thank for the support done by Institute of Agriculture and Animal Science, Lamjung (Tribhuvan University, Nepal). Also, we'd like to express our gratitude to Mr. Rameshwor Pudasaini (the Assistant Professor of Plant Protection Department). We're also highly thankful to Dr. Doug Yanega (U.S.A), Dr. Harry Brailovsky (Mexico), Dr. Dávid Rédei (Hungary) and Mr. Shankararaman H. (India) for providing the necessary papers, clarifying to our many queries and helping us regarding some identifications.

\section{REFERENCES CITED}

Arnett, R. H. (2000). American Insects: A Handbook of the Insects of America North of Mexico (2 ${ }^{\text {nd }}$ ed.). Florida: CRC Press.

Brailovsky, H. (2014). Illustrated key for identification of the species included in the genus Leptoglossus (Hemiptera: Heteroptera: COREIDAE: Coreinae: Anisoscelini), and description of five new species and new synonyms. Zootaxa, 3794(1): 143-178. doi: 10.11646/zootaxa.3794.1.7

Coreoidea Species File http://coreoidea.speciesfile.org/HomePage/Coreoidea/HomePage.aspx 2018.01.25

Chakrabart, S. P., Ghosh L. K., \& Basu R. C. (1994). Basu Ze On a Collection of Hemiptera from Namdapha Biosphere Reserve in Arunachal Pradesh, India: 161.

Distant, W.L. (1902) Rhynchota,-Vol.1 (Heteroptera). Pp.xxvii+438 in: W.T. Blanford (ed.) The Fauna of British India, including Ceylon and Burma. London. Secretary of State for India. Taylor and Francis. 
Distant, W.L. (1910) Rhynchota: Homoptera: Appendix. Heteroptera: Addenda. The fauna of British India, including Ceylon and Burma. Secretary of State for India, London, 5: 151-273.

Eisner, T. (2003). For Love of Insects. Belknap Press of Harvard. University Press, Cambridge, Massachusetts.

Fent, M. \& Kment, P. (2011). First record of the invasive western conifer seed bug Leptoglossus occidentalis (Heteroptera: Coreidae) in Turkey. North-Western Journal of Zoology, 7(1): 7280.

Gupta, R., \& Singh, D. (2013). Taxonomic notes on five species of the genus Cletus Stal (Heteroptera: Coreidae) from northern India with particular reference to their female genitalia. Journal of Entomology and Zoology Stuides. Journal of Entomology and Zoology Studies, 1(6): 44-51.

Gupta, R. (2013). Taxonomic studies on families coreidae and lygaeidae (hemiptera: heteroptera) from north India supplemented with rapid markers. Doctrate Thesis. Punjabi University, Patiala, India.

Henry, T. J. (2009). Biodiversity of Heteroptera. In Foottit E, Adler P (Eds), InsectBiodiversity: Science and Society. Wiley- Blackwell, Oxford.

Joshi, S.L., \& Manandhar, D.N. (Eds.). (2001). Reference Insects of Nepal. Khumaltar, Lalitpur, Kathmandu, Nepal: Entomology Division, Nepal Agriculture Research Council.

Kumar, R. (1966). Studies on the biology, immature stages, and relative growth of some Australian bugs of superfamily Coreoidea (Hemiptera: Heteroptera). Aust. J. Zool., 14: 895-991.

Maes, J.-M. \& Goellner-Scheiding, U. (1993). Catálogo de los Coreoidea (Heteroptera) de Nicaragua. Revista Nicaraguense de Entomología, 25: 1-19.

Mitchell, P.L. (2000). Leaf-footed bugs (Coreidae). In: Schaefer CW, Panizzi AR (Eds) Heteroptera of Economic Importance. CRC Press, Boca Raton, FL.

Natural History Museum Data Portal http://data.nhm.ac.uk/dataset/collection-specimens/resource 2018.01.21

Packauskas, R. (2010). Catalog of the Coreidae, or Leaf-Footed Bugs, of the New World. Fort Hays Studies, Fourth Series, Number 5, Fort Hays, 270 pp.

Prabakar, D. (2015). The biogeographical distribution of species of the superfamily Coreoidea: Hemiptera in India. Biolife, 3(1): 291-316.

Steinbauer, M.L. (1996). Notes on extra-phytophagous food sources of Gelonus tasmanicus (Le Guilloi) (Hemiptera: Coreidae) and Dindymus versicolor (Herrich-Schaeffer) (Hemiptera: Pyrrhocoridae). Aust. Entomol. Mag. 23(4): 121-124.

Thapa, V. K. (2000). An Inventory of Nepal's Insects Volume III (Hemiptera, Hymenoptera, Coleoptera \& Diptera) (pp. 50-51). Kathmandu, Nepal: IUCN. 